\title{
A CARNAVALIZAÇÃO NO CINEMA: UMA ABORDAGEM A PARTIR DO IDEÁRIO BAKHTINIANO
}

\author{
Carnivalization in cinema: an approach from the Bakhtinian ideology
}

La Carnavalización en el cine: un enfoque a partir del ideal bakhtiniano

Alexandre Silva Guerreiro

Doutor em Comunicação pelo PPGCOM-UFF

alexandreguerreiro@hotmail.com

\section{Resumo}

O conceito de cosmovisão carnavalesca é central para pensar a obra de Mikhail Bakhtin. Ao lado de outros conceitos que compõem o ideário bakhtiniano, a carnavalização é uma ferramenta que permite a construção de novos olhares sobre a obra de arte. Este trabalho tem como objetivo mapear uma série de conceitos dentro do universo bakhtiniano, traçando a complementariedade existente entre eles para, em seguida, construir uma análise panorâmica do que chamaremos de cinema carnavalizado. A partir de filmes que dialogam direta ou indiretamente com esses conceitos, procuramos compor um cenário em que se torne possível apontar uma tradição da carnavalização no cinema.

Palavras-chave: Bakhtin. Carnavalização. Cinema.

\begin{abstract}
The concept of carnivalization is central to approach of Mikhail Bakhtin's work. Alongside other concepts that make up the Bakhtinian ideology, carnivalization is a tool that allows the construction of new looks on the work of art. This work aims to map a series of concepts within the Bakhtinian universe, tracing the complementarity between them and then constructing a panoramic analysis of what we will call carnivalized cinema. From films that dialogue directly or indirectly with these concepts, we try to compose a scenario in which it becomes possible to point out a tradition of carnivalization in the cinema.
\end{abstract}

Key words: Bakhtin. Carnivalization. Cinema.

\section{Resumen}

El concepto de cosmovisión carnavalesca es central para pensar la obra de Mikhail Bakhtin. Al lado de otros conceptos que componen el ideal bakhtiniano, la carnavalización es una herramienta que permite la construcción de nuevas miradas sobre la obra de arte. Este trabajo tiene como objetivo mapear una serie de conceptos dentro del universo bakhtiniano, trazando la complementariedad existente entre ellos para luego construir un análisis panorámico de lo que llamaremos cine carnavalizado. A partir de películas que dialogan directa o indirectamente con esos conceptos, buscamos componer un escenario en el que sea posible apuntar una tradición de la carnavalización en el cine.

Palabras clave: Bakhtin. Carnavalización. Cinema. 


\section{INTRODUÇÃO}

O conceito de cosmovisão carnavalesca é peça chave no pensamento de Bakhtin. Além da carnavalização, o autor desenvolveu também uma série de conceitos que fundamentam seu trabalho e que ajudam a melhor compreender a aplicabilidade do carnaval como instrumento de análise. De um lado, há os elementos que compõem diretamente o carnavalizado, como a paródia e a sátira menipeia. De outro, os conceitos de polifonia, dialogismo e intertextualidade.

Este artigo propõe pensar o ideário bakhtiniano para, em seguida, lançar um olhar sobre o cinema. Antes de iniciarmos uma explanação sobre o cinema carnavalizado, propomos uma breve revisão dos conceitos aqui citados, promovendo uma atualização dos mesmos a partir de autores que sobre eles discorreram mais recentemente.

A obra de Bakhtin e, mais especificamente, o conceito de carnavalização, já alimentaram diversas abordagens da sétima arte. Pretendemos, através dessa abordagem, evidenciar de que maneira os conceitos bakhtinianos são interdependentes e como um visionamento de filmes pautado por tais conceitos redimensiona o alcance da análise fílmica. Ao adotar a carnavalização como ferramenta de análise, é o próprio cinema que se transforma ao abrir-se para novas possibilidades de recepção.

\section{BREVE ABORDAGEM DO IDEÁRIO BAKHTINIANO: DO DIALOGISMO À COSMOVISÃO CARNAVALESCA}

A quantidade de leituras da obra bakhtiniana, de onde apreendemos a necessidade de constantemente passar a limpo as interpretações de seus conceitos, está expressa em Robert Stam.

Cada país e cada escola, porém, parecem ter seu próprio "Bakhtin", e não raro se observa a existência de Bakhtins diversos no mesmo país. Assim, encontramos Bakhtin, o formalista, Bakhtin, o antiformalista, e lado a lado com Bakhtin, o fenomenologista, Bakhtin, o marxista, e Bakhtin, o pósestruturalista (STAM, 1992, p. 9). 
Dependendo do enfoque dado ao instrumental teórico criado por Bakhtin, alguns conceitos podem figurar em primeiro plano enquanto outros ocupam um lugar menor. Mas é inevitável notar sua existência e refletir sobre eles. Para Diana Luz Pessoa de Barros, por exemplo, o fundamental na obra de Bakhtin é a ideia de dialogismo, já que "o princípio dialógico permeia a concepção de Bakhtin de linguagem e (...) de mundo, de vida" (BARROS, 2003, p. 2).

O princípio do dialogismo amplia as possibilidades de crítica da obra de arte, em especial, e da leitura de mundo, de uma forma geral. Nesse sentido, a contribuição desse conceito provocou uma verdadeira revolução no campo da produção intelectual. Bakhtin critica a fetichização da arte bem como o enfoque concentrado no ponto de vista do observador que analisa a obra. Segundo ele, é preciso um entendimento em todos os sentidos para que se possa superar tanto o formalismo quanto o ideologismo. Essa ideia está imbuída do sentido maior que é o dialogismo, pelo qual nenhuma análise deve estar fechada em si, o que pressupõe o diálogo entre as mais diversas correntes. Um discurso traz, em seu seio, inúmeros outros discursos que o formam.

A presença do discurso do outro no eu é exemplificada por Bakhtin através de uma reflexão sobre a aprendizagem da fala por uma criança, que constrói seu discurso totalmente baseado no discurso do outro, pai, mãe, professor etc. Para Robert Stam, “Toda a obra de Bakhtin gira em torno desse eixo do eu e do outro, e da concepção de que a vida é vivida nas fronteiras entre a particularidade de nossa experiência individual e a auto-experiência de outros" (STAM, 1992, p. 18).

Em seu estudo da obra de Dostoiévski, Bakhtin chama atenção para a existência de várias vozes em seus romances, o que não tinha sido percebido pela crítica literária até então. A obra de Dostoiévski passa a ser associada à ideia de romance polifônico, contrapondo-se ao romance monofônico.

O princípio da polifonia implica na afirmação do eu do outro não como objeto, mas como sujeito. O mundo monológico da consciência do autor dá lugar à autoconsciência dos personagens. A visão de mundo do autor, então, passa a ser apenas uma das visões de mundo presentes no texto, o que torna a obra aberta, incompleta, já que não cabe mais ao autor explicar, através de uma visão monológica, o lugar do outro (BAKHTIN, 1982, p. 6, 36).

Isso tem uma implicação direta na questão ideológica contida no texto, já que a existência do outro enquanto sujeito acaba por promover a confluência de vozes de discursos diferentes, ou mesmo contraditórios, dentro de um mesmo universo. A polifonia, então, tem 
um caráter ideológico que precisa ser percebido, e que vem ao encontro do ideário bakhtiniano de não exclusão, ao considerar as inúmeras vozes que estão presentes em cada discurso, vozes essas que podem ser heterogêneas e contraditórias.

Portanto, a polifonia permite que essas vozes permaneçam como sujeitos, audíveis, ao invés de serem filtradas ou alteradas, enquadradas na voz do autor, o que tornaria o texto monofônico. É preciso saber "“representar a ideia do outro", conservando-lhe toda a plenivalência enquanto ideia, mas mantendo simultaneamente a distância, sem afirmá-la, nem fundi-la com sua própria ideologia representada" (BAKHTIN, 1981, p. 71).

Uma das principais contribuições do ideário bakhtiniano reside no fato de que o outro existe como sujeito. Esse é o princípio elementar da polifonia. É a concepção, a aceitação do outro como sujeito, que permite um efeito polifônico ao texto. A partir disso, Bakhtin instaura uma abordagem tolerante com as diferenças, absolutamente aberta às mais diversas influências dos pensamentos, ideologias, correntes que a precederam. O pensamento e suas manifestações culturais passam a fazer parte de uma tradição humana e do acúmulo de sua experiência.

As raízes da cosmovisão carnavalesca foram localizadas por Bakhtin na sátira menipeia e no diálogo socrático. Essas duas variações desenvolveram-se ainda no período da Antiguidade Clássica, sendo que a sátira menipeia seria uma derivação do diálogo socrático. A estrutura do diálogo socrático, que pressupunha a voz do outro e não só a do autor, fomenta a discussão das origens da polifonia.

Bakhtin define o "diálogo socrático" como um gênero cômico-sério saído do carnaval. Se, como afirma insistentemente, o carnaval é ambivalência profunda e recusa de soluções, se a mentalidade carnavalesca é inimiga das convenções, então a recusa de uma decisão e o questionamento das idéias recebidas, duas táticas fundadas na maneira pela qual Sócrates concebe a natureza própria da verdade, sugerem com efeito o clima ou o modo carnavalesco (HAYMAN, 1980, p. 33).

Ao buscar o princípio polifônico nas origens do gênero cômico, Bakhtin localiza a nascente da sátira. Leonor Lopes Fávero afirma que a sátira menipeia "deve seu nome ao filósofo Ménippe, de Godare (séc. III a.C.), que lhe deu a forma clássica, tendo sido Varrão (séc. I. a.C.) o primeiro a empregar o termo para designar um gênero particular, intitulando sua obra Saturae Menippeae" (FÁVERO, 2003, p. 52). 
Bakhtin elenca diversas particularidades da sátira menipeia, num total de catorze ${ }^{1}$, dentre as quais podemos citar a presença constante do elemento cômico, a libertação das limitações históricas e a total liberdade de invenção filosófica e temática, a síncrese, a infração às regras do bom-tom, o uso de contrastes violentos, a representação de estados psíquicos anormais, a opção pelos problemas sociopolíticos contemporâneos. A sátira menipeia está no cerne da questão da carnavalização do mundo, funcionando a partir do princípio polifônico na arte (STAM, 1992, p. 38-39).

Um dos recursos básicos da sátira menipeia enquanto gênero é a capacidade de infiltrar-se em outros gêneros. Isso, certamente, garante sua permanência, através de suas características mais básicas, tais como o uso de contrastes agudos, sendo ainda comuns escândalos, comportamentos excêntricos, violações das normas comportamentais (BAKHTIN, 1982, p. 101).

Sendo assim, a menipeia, pelas suas características mais corriqueiras, é fundamental para o desenvolvimento da noção de carnavalização. Para Bakhtin, não há como separar sátira menipeia e paródia dentro do conceito maior de carnavalização. Ao colocar a questão da cosmovisão carnavalesca em foco no seu repertório teórico, ele acabou por valorizar gêneros considerados secundários.

Etimologicamente, paródia significa canto paralelo, o que pressupõe a ideia de vozes se sobrepondo, funcionando como contracanto em relação à outra voz que lhe é anterior. Foi Aristóteles quem categorizou a paródia como arte, a partir de Hegemon de Tarso, que usou pela primeira vez, no séc V a.C., esse gênero infiltrado no gênero épico, ao colocar "os homens como seres comuns, inseridos na vida cotidiana e não como seres superiores" (FÁVERO, 2003, p. 49).

Os conceitos de sátira e paródia são elementos fundamentais na elaboração da cosmovisão carnavalesca. A paródia atua dentro da sátira menipeia e apresenta-se como essencialmente intertextual e polifônica, já que seu texto pressupõe textos anteriores que são por ela negados, relativizados, transformados. "Na paródia a fusão de vozes é impossível, pois elas provêm de mundos diferentes; elas se fazem ouvir numa leitura polifônica - a polifonia é uma de suas características" (FÁVERO, 2003, p.55).

\footnotetext{
${ }^{1}$ Suzana Camargo aplica as catorze particularidades fundamentais enumeradas por Bakhtin ao livro de Mário de Andrade, em Macunaíma: ruptura e tradição (São Paulo: João Farkas/Massao Ohno, 1977).
} 
Em tempo, vale considerar as colocações de Flávio R. Kothe acerca da paródia, o que representa um certo pensamento desabonador sobre a mesma. Sua abordagem atribui à paródia um lugar inferior, a partir de uma separação entre paródia e estilização.

A paródia procura rebaixar um texto, um estilo, uma escola; a estilização, que, como a paródia, também tem alguma outra obra ou tendência anterior como referência, diferencia-se porque procura criar uma obra que seja de nível mais elevado e que não viva mais apenas para negar algo anterior (KOTHE, 1980, p. 99).

Seguindo essa lógica, ele atribui à paródia apenas o que considera destituído de qualidade, cabendo à estilização todos os méritos de obras ditas maiores. "A estilização é uma paródia que conseguiu ser uma grande obra de arte, enquanto que a paródia é uma estilização que artisticamente não deu certo e se situa, portanto, na parte baixa da pirâmide" (KOTHE, 1980, p. 102).

Tais apontamentos partem de um princípio que considera pejorativamente o rebaixamento promovido pela paródia. Não se trata, através desse rebaixamento, de tecer considerações acerca do que tem ou não qualidade. Antes, é preciso descobrir que a premissa bakhtiniana é a de valorização do que até então permanecia no domínio do extraoficial e do popular.

Ao discorrer sobre esse assunto, Bakhtin contribui para a diferenciação e valorização tanto da paródia quanto da estilização, ao afirmar em relação à paródia que

Nesta, como na estilização, o autor fala a linguagem do outro, porém, diferentemente da estilização, reveste essa linguagem de orientação significativa diametralmente oposta à orientação do outro. (...) O discurso se converte em palco de luta entre duas vozes. Por isto é impossível a fusão de vozes na paródia, como o é possível na estilização (BAKHTIN, 1981, p. 168).

Afonso Romano de Sant'Anna, na contramão do que afirma Kothe, expõe dois textos precisos de Tynianov e Bakhtin nos quais fica claro que a separação entre paródia e estilização nada tem a ver com qualidade, e sim com o sentido tomado pela leitura do texto original. Assim, a paródia pode seguir vários caminhos, porém todos eles inversos ao da obra que suscitou a paródia. E ainda que geralmente esteja vinculada ao riso, Tynianov afirma que a paródia de uma comédia pode ser uma tragédia. Ao contrário, a estilização deve seguir um único caminho, o mesmo seguido pelo autor da obra original (SANT'ANNA, 1985, p. 13-15).

Manuseando o conceito de cultura popular, Bakhtin discorre sobre as festas populares medievais, em especial o carnaval, como sendo um segundo mundo vivido pelo povo, que 
degenera e subverte o mundo oficial. Esse carnaval serve de base para que se formule a ideia da cosmovisão carnavalesca, o que não significa, segundo o próprio Bakhtin, traduzir o carnaval como instrumento de análise. Aqui, fica claro que o conceito não está fundamentado na ideia de uma tradução, mas de uma transposição que amplia significativamente as possibilidades de análise da obra de arte. O carnaval, segundo Bakthin,

É uma forma sincrética de espetáculo de caráter ritual, muito complexa, variada, que, sob base carnavalesca geral, apresenta diversos matizes e variações dependendo da diferença de épocas, povos e festejos particulares. $\mathrm{O}$ carnaval criou toda uma linguagem de formas concreto-sensoriais simbólicas, entre grandes e complexas ações de massas e gestos carnavalescos. Essa linguagem exprime de maneira diversificada e, pode-se dizer, bem articulada (como toda linguagem) uma cosmovisão carnavalesca una (porém complexa), que lhe penetra todas as formas. Tal linguagem não pode ser traduzida com o menor grau de plenitude e adequação para a linguagem verbal, especialmente para a linguagem dos conceitos abstratos, no entanto é suscetível de certa transposição para a linguagem cognata, por caráter concretamente sensorial, das imagens artísticas (BAKHTIN, 1982, p. 105).

A concepção bakhtiniana do carnaval passa pela definição de três grandes categorias. Bakhtin estabelece que a ideia maior do carnaval ultrapassa a materialidade das festas populares, que constituem a primeira categoria, a saber, as formas dos ritos e espetáculos, desembocando em outras duas categorias, a das obras cômicas verbais e a das diversas formas e gêneros do vocabulário familiar e grosseiro. É essa visão amplificada do fenômeno do carnaval que permitiu a formulação do conceito de carnavalização e outros conceitos correlatos.

As formas dos ritos e espetáculos traduzem-se como o carnaval concreto, das festividades carnavalescas que rompiam com as tradições religiosas e oficiais, e instauravam outra tradição, a do cômico-popular, do riso, do extraoficial. Segundo Bakhtin, os que participavam dessas festividades "pareciam ter construído, ao lado do mundo oficial, "um segundo mundo" e "uma segunda vida" (...). Isso criava uma espécie de "dualidade do mundo""' (BAKHTIN, 1993, p.5).

As obras cômicas verbais, segundo Bakhtin, poderiam vir tanto do folclore e de uma tradição oral, quanto da literatura, através de uma absorção das manifestações de ordem carnavalesca. Assim, tanto o linguajar quanto o riso festivo próprio do carnaval eram usados, formulando essa literatura cômica própria da Idade Média, e que teve no Renascimento seu apogeu. 
As diversas formas e gêneros do vocabulário familiar e grosseiro foram apontadas por Bakhtin como essenciais para se entender o carnaval como um todo. Esse vocabulário específico está presente tanto nas festividades populares como na literatura cômica que se formulou no período. Era uma forma nova de se comunicar, imbuída do espírito do carnaval, que se desdobrava no uso frequente de grosserias. O uso desse linguajar específico se dá graças à convivência familiar entre os homens que o carnaval suscita.

É importante notar que, ao se referir ao carnaval, Bakhtin não evoca as manifestações carnavalescas de sua época. Para entender o conceito de carnavalização proposto por Bakhtin, é preciso entender as diferenças que ocorreram no carnaval.

É necessário deixar de lado, ainda, a estreita concepção espetaculoso-teatral do carnaval, bastante característica dos tempos modernos. Para interpretar corretamente o carnaval é necessário tomá-lo nas suas origens e no seu apogeu, ou seja, na Antiguidade, na Idade Média e, por último, no Renascimento (BAKHTIN, 1982, p. 138).

Uma tradição secular de festas populares de cunho carnavalesco foi responsável pelo desenvolvimento de uma visão de mundo avessa ao mundo oficial, diário. A ideia de subversão está no cerne da questão da cosmovisão carnavalesca. Durante séculos, os homens conviveram com e no carnaval, e é natural que tenham se contaminado pela visão de mundo própria do universo de inversões e rupturas dos festivos carnavalescos.

Essa contaminação nos autoriza supor que determinadas obras não se enquadrem nos cânones clássicos da literatura e da arte em geral. O conceito de cosmovisão carnavalesca vem preencher essa lacuna, batizar uma prática de leitura do mundo contaminada pela essência do carnaval. A carnavalização encontra sua melhor definição nas palavras de seu formulador.

Chamaremos literatura carnavalizada à literatura que, direta ou indiretamente, através de diversos elos mediadores, sofreu a influência de diferentes modalidades de folclore carnavalesco (antigo ou medieval). Todo o campo do cômico-sério constitui o primeiro exemplo desse tipo de literatura. Para nós, o problema da carnavalização na literatura é uma das importantíssimas questões de poética histórica, predominante de poética dos gêneros (BAKHTIN, 1982, p. 92).

Ao aproximar o homem do mundo, o homem do homem, o conceito de carnavalização promove uma transformação que nada tem a ver com o questionamento da qualidade artística da obra, mas ressalta o tratamento que temas que não são notadamente nobres podem receber. Isso porque a carnavalização descortina uma pluralidade de estilos e de vozes na corrente do gênero cômico. 
$\mathrm{Na}$ medida em que promove a inversão ou libertação do mundo oficial, a carnavalização permite o surgimento do humano, mesmo dentro da história oficial. A partir de um tratamento carnavalizante, até os reis tendem a ser percebidos como homens, através de estratégias de coroação-destronamento, próprias da cosmovisão carnavalesca. Assim, a obra carnavalizada "opõe-se somente à seriedade oficial unilateral e sombria, gerada pelo medo, dogmática, hostil aos processos de formação e à mudança, tendente a absolutizar um dado estado da existência e do sistema social" (BAKHTIN, 1982, p. 138).

Dentre as muitas características que podem ser ressaltadas quando enfocamos a carnavalização, a ideia de inversão, sem dúvida, assume destaque pois está no cerne da própria abordagem do carnaval feita por Bakhtin. A inversão que o carnaval promove na vida cotidiana foi responsável pela sedimentação de uma visão de mundo carnavalizada, mas é importante notar de que maneira essa inversão se manifesta.

Um dos pontos fundamentais é o fato do carnaval ser responsável pela aproximação entre os homens, que na vida cotidiana permanecem afastados social e hierarquicamente. Essa aproximação específica promovida pelo carnaval transforma-se, então, no livre contato familiar entre os homens. Instaura-se um novo modo de relações interpessoais, a partir da formulação do contato livre e familiar.

A esse conceito, Bakhtin atrela outra característica importante do mundo carnavalizado, a saber, a excentricidade. Para ele,

A "excentricidade" é uma categoria específica da cosmovisão carnavalesca, organicamente relacionada com a categoria do contato familiar; ela permite que se revelem e se expressem - em forma concreto-sensorial - os aspectos ocultos da natureza humana (BAKHTIN, 1981, p. 106).

Além disso, uma das mais fortes características do carnavalizado é o uso de contrastes agudos, as mésalliances, através do confronto entre sagrado e profano, alto e baixo. Assim, através de categorias dicotômicas, o carnaval promove a aproximação dos "elementos antes fechados, separados e distanciados uns dos outros pela cosmovisão hierárquica extracarnavalesca" (BAKHTIN, 1981, p. 106).

A profanação é outra marca própria da carnavalização, ligada ao poder do carnaval de transformar o que é sagrado, intocado, oficial, instituindo-se, aqui, os sacrilégios carnavalescos. Essa e as demais categorias se manifestam no carnaval através das ações carnavalescas, dentre as quais se destaca a prática da coroação-destronamento, constante em festejos os mais variados. 
A cerimônia de destronamento é como se encerrasse a coroação, da qual é inseparável (...). Através dela transparece uma nova coroação. O carnaval triunfa sobre a mudança, sobre o processo propriamente dito de mudança e não precisamente sobre aquilo que muda (...) era precisamente no ritual do destronamento que se manifestava com nitidez especial a ênfase carnavalesca das mudanças e renovações (BAKHTIN, 1981, p.107-8).

Nas ações carnavalescas, podemos perceber a presença de todas as categorias enumeradas anteriormente. Assim, a ação da coroação-destronamento se caracteriza pelo princípio das mésalliances, pela profanação, pelo contato livre e familiar. O uso de um linguajar comum próprio de uma concepção carnavalesca do mundo surge graças ao contato livre e familiar que o carnaval promove.

Os conceitos e categorias até aqui comentados atuam ativamente na composição da cosmovisão carnavalesca. Através deles, Bakhtin plantou novas possibilidades de análise em diversos textos: música, teatro, literatura, cinema.

\section{GRANDE ANGULAR CARNAVALESCA}

A carnavalização pode ser notada, em maior ou menor grau, no cinema brasileiro e estrangeiro. Pretendemos, aqui, fazer uma breve explanação sobre a carnavalização no cinema, não sendo nossa intenção esgotar o assunto. Nossa proposta nesse momento é promover uma análise panorâmica da produção cinematográfica de raízes carnavalescas. $\mathrm{O}$ efeito dessa análise poderá ser o de uma lente grande angular, que distorce o que vê para ver mais coisas dentro do quadro. Eis o nosso recurso para pincelar, em pouco mais de um século de cinema, os conceitos até então expostos.

Vale registrar que Tatiana Bubnova (2000), ao refletir sobre a permanência (e resistência) do carnaval como dispositivo teórico, aponta sua contribuição para diversos campos do conhecimento. Entendemos, aqui, o cinema como terreno fértil no qual a cosmovisão carnavalesca sempre floresceu, ainda que de maneiras variadas. Nesse sentido, o interesse pela leitura de determinados filmes sob o ideário bakhtiniano, particularmente a carnavalização, está justamente em articular filmes de universos distintos a partir dessa outra possibilidade de leitura. De certa forma, é através do legado de Bakhtin que estes filmes entram em sintonia e passam a integrar o que chamaremos de cinema carnavalizado.

Por outro lado, não é apenas para o exercício de articular os filmes sob a chave da carnavalização que nossos esforços estão voltados. Entender que o cinema, como expressão artística e cultural, tem relevância quando pensamos o conceito de carnavalização, significa 
ampliar o que Bakhtin considerava como obras cômicas e verbais, que podiam ter origem tanto no folclore quanto na literatura. Nossa análise, nesse sentido, busca amplificar o alcance do repertório bakhtiniano para além do que o próprio Bakhtin assumiu como objeto de análise. As conquistas para o campo do cinema são notáveis, tanto no que diz respeito à linguagem quanto à estética audiovisual. Assim, pensar os diversos estilos e escolas cinematográficas, os recursos de roteiro, os figurinos, os movimentos de câmera, as inúmeras escolhas de cada cineasta e sua equipe, tem na carnavalização um poderoso propulsor.

Podemos considerar que o cinema demorou a edificar uma tradição carnavalesca. Algumas situações que encontramos nos anos 60 são impensáveis nos filmes realizados no início do século. Assim, precisaremos esperar décadas para que recursos próprios da carnavalização tenham efetivo espaço. Os épicos religiosos hollywoodianos do início do século XX se esmeravam em produções cada vez mais elaboradas, e nem o público, nem o cinema pareciam muito interessados na carnavalização propriamente dita, lançando mão apenas mais tarde, como veremos, de recursos tais como a profanação e outras inversões carnavalescas. O cinema clássico-narrativo imperou e fez escola na primeira metade do século XX, mas a segunda metade do século viu o cinema experimentar reviravoltas no campo da linguagem e da ideologia que perpassavam os filmes. As cinematografias nacionais se insurgiram com força contra o cinema hegemônico, buscando espaço onde pudessem respirar livremente, o que ocasionou mais frequentemente o uso da carnavalização no cinema.

No entanto, não sem algum esforço, podemos encontrar, já nas primeiras décadas do cinema, alguns filmes que utilizaram, ainda que de maneira incipiente, elementos da carnavalização cinematográfica. Nos anos 30, por exemplo, no filme Pigmaleão ${ }^{2}$ (Pygmalion, de Anthony Asquith e Leslie Howard, Inglaterra, 1938), encontramos uma dupla utilização de características da carnavalização. Trata-se da clássica história de Eliza Dollitle, uma paupérrima vendedora de flores que é transformada em dama pelo professor de fonética Henri Higgins. Durante esse processo, fica clara a presença do espírito das mésalliances, enquanto acompanhamos a aprendiz Eliza Dollitle se deslocar da condição de mendiga a de uma grande dama da sociedade. Além disso, a questão do linguajar comum é extremamente explorada no filme. O desafio do professor é fazer com que Eliza fale corretamente. O popular aparece, assim, através do linguajar comum de Eliza e seu sotaque que denota sua origem social. Mais

\footnotetext{
${ }^{2}$ Inspirado na peça escrita por George Bernard Shaw.
} 
tarde, nos anos 60, essa mesma história foi transformada em musical dirigido por George Cukor $^{3}$, mantendo o aspecto carnavalesco que, aqui, é apenas de ordem temática.

Porém, um dos mais emblemáticos musicais que servem a nossa análise é Entre a Loura e a Morena (The Gang's all here, de Busby Berkeley, EUA, 1943), filme que conta com a presença de Carmem Miranda, cuja sexualidade era colocada em evidência em suas participações sempre marcantes nos filmes hollywoodianos. Carmem encarnou a latina liberal e ajudou a montar um estereótipo exuberante da mulher latinoamericana, o que pode ser também atribuído a carreiras similares, como a da porto-riquenha Rita Moreno. Em todo caso, Carmem tem alguns números musicais no filme em questão, e um deles em particular merece atenção especial. Trata-se da música The lady in the tutti-frutti hat, que Carmem canta entre bananas gigantes e jovens latinas que formam os caleidoscópios humanos tão representativos da obra de Berkeley. A carnavalização evidente se dá pela exuberância e pelo exagero. Os versos da canção interpretada por Carmem dão o tom dessa exuberância e da sexualidade da mulher latina.

\section{Americanos tell me that my hat is high \\ Because I will not take it off to kiss a guy \\ But if I ever start to take it off, ai ai... \\ I "do" that once for Johnny Smith \\ And he "is" very happy with \\ The lady in the tutti-frutti hat ${ }^{4}$}

O chapéu gigante do título da canção tornou-se uma imagem-símbolo de Carmem Miranda em sua passagem pelos EUA. O exagero está nas formas acentuadas e na própria construção do estereótipo para o qual Carmem contribuiu. Mas o gênero musical é muito rico e complexo. Podemos perceber variáveis que recolocam cada filme em gêneros mais gerais, podendo um musical oscilar do drama extremo à absoluta comédia. Esse é um gênero dado ao exagero e à exuberância tão marcantes em Carmem. Muito além de Entre a Loura e a Morena, um universo de filmes pode ser citado, mas, via de regra, o exagero é uma das marcas recorrentes do gênero.

Nos anos 50, um dos musicais mais aclamados de todos os tempos será todo construído sobre situações baseadas na parodização do próprio cinema. Trata-se de

\footnotetext{
${ }^{3}$ Trata-se do filme Minha Bela Dama (My Fair Lady, EUA, 1964).

${ }^{4}$ Música composta por Leo Robin e Harry Warren. Os tempos verbais propositadamente errados reforçam a latinidade da personagem: "Americanos me dizem que meu chapéu é alto / Porque eu não vou tirá-lo para beijar um rapaz / Mas se eu começo a tirá-lo, ai... ai... / Eu faço isso uma vez para Johnny Smith / E ele está muito feliz com / A moça com o chapéu de tuttifrutti." (tradução nossa).
} 
Cantando na Chuva (Singin'n the rain, de Stanley Donen e Gene Kelly, EUA, 1952), que aborda com muito humor e irreverência a revolução sonora que mudou os rumos do cinema a partir de 1927. A paródia, aqui, não toma apenas um texto, um filme, como objeto original. É a práxis do cinema que recebe um tratamento paródico, numa representação do esforço técnico no ajuste necessário implantado pelo advento do som, o que está na origem do cinema de gênero musical.

Cantando na Chuva põe em xeque a própria questão do star system, através da tentativa de manutenção da fictícia estrela do cinema mudo, Lina Lamont, no elenco de um filme que passa, instantaneamente, para a condição de filme falado. Sua voz aguda causa um desconforto na plateia, que reage com um riso histérico à performance da estrela de outrora. Sua salvação será Kathy, uma dubladora, até que Lina seja desmascarada no final. O antagonismo entre as estrelas e, mais uma vez, o exagero característico do cinema musical, nos autorizam a pensar na presença de elementos da carnavalização. No entanto, em todos os exemplos até então citados, essa carnavalização é incipiente e temática. Será preciso esperar os anos 60 para que a carnavalização comece a se dar de maneira mais efetiva na sétima arte.

O Incrível Exército de Brancaleone (L’Armata Brancaleone, de Mário Moniceli, Itália, 1965) é o primeiro grande filme carnavalizado de nossa análise panorâmica. Trata-se de uma paródia a Dom Quixote, de Cervantes, que serve como trampolim para uma abordagem até então inédita da História. Virada de cabeça para baixo, desglamourizada, a História enfocada é a da Baixa Idade Média, período marcado pela desgraça humana causada pela fome, pela peste negra e pela guerra. Essa trilogia de caráter trágico, no entanto, não impede que o filme promova uma verdadeira reviravolta histórica calcada no espírito carnavalesco do riso. Aqui, a profanação está presente já no argumento, através do enfoque dos cruzados que tentam expandir o alcance do cristianismo, mas que para isso vão acumulando gags pelo caminho. Ao contrário dos filmes épicos hollywoodianos, Brancaleone capta a essência da época na simplicidade, na sujeira, na ausência de austeridade, e termina por ser um dos melhores estudos sobre o período medieval, sendo ainda hoje uma referência interessante sobre o assunto.

Um dos filmes mais exemplares em que podemos localizar a carnavalização no cinema é, sem dúvida, A Vida de Brian (Monty Python's Life of Brian, de Terry Jones, Inglaterra, 1979). A partir de situações cômicas, alguns tabus religiosos vão sendo ridicularizados, no sentido carnavalesco da palavra, e as passagens do novo testamento são, uma a uma, profanadas pelo viés da carnavalização. Para começar, os três reis magos entram em uma 
manjedoura onde uma criança acabara de nascer. Naturalmente, era a manjedoura errada, e Brian, a criança, passará o resto de sua vida tendo que enfrentar a concorrência do outro cara da Galileia. O sermão da montanha também é devidamente profanado, e a câmera se situa afastada da montanha para registrar o conflito entre os ouvintes que, na verdade, nada conseguem ouvir do que está sendo dito. O filme brinca com as imagens dos épicos religiosos, tão comuns na Hollywood de décadas anteriores.

Os anos 80 têm um dos melhores exemplos da cosmovisão carnavalesca no cinema no filme O Prisioneiro do Rio (Prisioner of Rio, de Lech Majewski, Inglaterra, Brasil, 1988). O lendário Ronald Biggs, perseguido no Brasil pelo histórico golpe que aplicara na Inglaterra, e que o fez milionário, refugia-se no carnaval carioca, o que não impede que a polícia inglesa mande um detetive para descobrir seu paradeiro. No final apoteótico, após ter cruzado com bandidos e travestis, o detetive inglês se vê no meio do desfile de uma escola de samba na Marquês de Sapucaí, onde se depara com o figurante Biggs. A fotografia, nesse instante, parece demonstrar a erudição do realizador do filme. Lentamente, a câmera vira de cabeça para baixo, a tela subverte o mundo real, oficial, assim como faz o carnaval, e num instante de euforia tudo fica invertido, o mundo vira de ponta-cabeça. Majewski parece estar familiarizado com o universo teórico de Bakhtin, promovendo um plano que, de certa forma, traduz a ideia da inversão carnavalesca, numa metáfora visual para explicar o bandido que se encontra no paraíso, através da carnavalizacão bakhtiniana e a inversão que esta promove ${ }^{5}$.

A inversão aqui se dá também no contexto, já que aquele que ocupa o lugar do bandido, e que, por definição, deveria buscar a sombra, ao contrário, se deixa filmar, feliz, fantasiado, apoteótico ${ }^{6}$. Um mendigo vestido de rei. Rompe-se no contexto (e no texto) as amarras do mundo oficial, tudo passa a ser permitido num mundo invertido. E não há lugar melhor para essa inversão, espetacularizada, do que a passarela do samba do Rio de Janeiro.

No Brasil, não é raro encontrar o carnaval no cinema. Como centro de excelência do carnaval contemporâneo, o Rio de Janeiro, ao se transformar no principal pólo de produção cinematográfica ao longo do século XX, imprimiu constantemente o carnaval em película, o que se deu de diversas maneiras.

O carnaval aparece de forma concreta em diversos títulos. Alguns exemplos são Quando o carnaval chegar (Cacá Diegues, 1972), Amor, Carnaval e Sonhos (Paulo Cesar

\footnotetext{
5 A esse respeito, Cf. O Brasil dos Gringos, imagens no cinema (Niterói: Intertexto, 2000) em que Tunico Amâncio faz uma análise plano a plano da sequência final do filme de Majewski.

${ }^{6} \mathrm{O}$ próprio Ronald Biggs aparece nessa sequência como figurante.
} 
Saraceni, 1972), Carnaval Atlântida (José Carlos Burle, 1952), ou mesmo no francês Orfeu do Carnaval (Orphée noir, de Marcel Camus, França, 1979) e ainda em Banda de Ipanema (Paulo Cesar Saraceni, 2003), dentre muitos outros. Este carnaval, a festa em si, não detém o monopólio da carnavalização na tela. Seguindo o que afirma Bakhtin, esta é apenas uma das três formas de carnavalização, como já vimos anteriormente, e que constituem a mentalidade que surge de uma tradição carnavalesca. Nesse sentido, Xica da Silva (Cacá Diegues, 1976), tem tantas ou mais ligações com os gêneros carnavalescos do que Orfeu (Cacá Diegues, 1999), no qual a Unidos do Viradouro, então sob o comando de Joãosinho Trinta, se afirma como um dos melhores exemplos da espetacularização do carnaval carioca já registrado em nossas telas.

Nos anos 40 e 50, o cinema da chanchada arejou nossa cinematografia com ricos exemplos de parodização. O diálogo estabelecido entre o cinema brasileiro e o cinema de Hollywood estava já nos títulos, como em Nem Sansão, Nem Dalila ou Matar ou Correr (ambos de Carlos Manga, e do mesmo ano de 1954), mas também na estilização dos musicais, gênero autóctone da indústria cinematográfica norte-americana, que nasce já com o marco do cinema sonoro como O Cantor de Jazz (The Jazz Singer, Alan Crosland, EUA, 1927) um híbrido da linguagem do cinema mudo com o cinema sonoro que surgia nas canções interpretadas por Al Jolson e na máxima do filme: "Vocês ainda não ouviram nada!" 7.

Filmes de grande bilheteria, paródias ao cinema norte-americano, obras que absorviam diretamente os cantores do rádio, herança das décadas anteriores, marcaram o tempo de existência do estúdio fundado por Moacir Fenelon e José Carlos Burle. Carnaval Atlântida, dirigido por Burle, é um dos mais expressivos filmes do período, e pode ser tomado como referência no estudo da carnavalização explícita promovida pelas chanchadas cariocas.

Contextualmente, os governos do período da redemocratização do Brasil pós-Estado Novo, entre 1946 e 1964, foram o pano de fundo na confecção das chanchadas dos anos 50. Em certo sentido, podemos notar uma sintonia entre o clima de humor e leveza dessa vertente cinematográfica em consonância com o panorama político que se montou naquela década, desde o Governo Dutra, com a constituição de 1946, que abolia os traços de autoritarismo do período anterior, até a política desenvolvimentista de JK, injetando um ânimo inédito na economia brasileira.

\footnotetext{
${ }^{7}$ No original: "You ain`t hear nothing yet!".
} 
Não que as chanchadas deixassem de colocar em pauta diversas críticas políticas e sociais, mas o tom dessa crítica era bem diferente do que foi feito a seguir, nos anos 60 . Assim, o cinema parece dialogar diretamente com a realidade em que se insere, já que em momentos ditos democráticos, os filmes mais críticos conseguiam destilar seus protestos de maneira mais palatável para o gosto dos políticos da situação, enquanto nos períodos politicamente mais conturbados, a própria forma de se realizar os filmes, e também os discursos dos mesmos, inauguravam um diálogo muito mais pesado com o contexto político, como no Cinema Novo, até redescobrir o deboche que marcará o Tropicalismo e o Cinema Marginal na virada dos anos 70 .

Ainda atentando para o contexto, vale lembrar as considerações feitas por João Luiz Vieira sobre o caráter comercial das paródias no âmbito da produção de chanchadas e do cinema brasileiro em geral (VIEIRA, 1983, p. 25). Em termos econômicos, tratava-se de pegar carona em grandes sucessos de bilheteria do cinema hollywoodiano. Algumas vezes, a parodização não ia muito além dos próprios títulos na ligação que os filmes tinham com o texto original. Manter-se atrelado a determinado filme norte-americano, pelo título, forma ou conteúdo, sendo o seu equivalente carnavalizado, poderia ser suficiente para garantir uma certa visibilidade para o produto nacional que jogava, então, com todas as armas de que dispunha.

Após a experiência do Cinema Novo, o cinema brasileiro dessa corrente estará intertextualmente presente em outros dois movimentos, o Cinema Marginal e o Tropicalismo. O Bandido da Luz Vermelha (Rogério Sganzerla, 1968) e Macunaíma (Joaquim Pedro de Andrade, 1969) permanecem como grandes exemplos não só dessas vertentes, como também da transformação na maneira como a carnavalização vai se manifestar no cinema após o Cinema Novo. Ao contrário deste, esses movimentos de grupo fizeram parte do período mais violento da ditadura militar, ficando numa posição diametralmente oposta ao cinema dos anos 50, quando o carnaval explícito fazia parte do menu do cinema brasileiro. “... o tropicalismo retomou contato com o carnaval e a paródia e "O bandido da luz vermelha" (...) dá mostras de uma abertura antropofágica e todas as influências intertextuais são citações que apontam para o diálogo entre este cinema e o produzido anteriormente na Atlântida” (STAM, 1992, p. 55).

A exacerbação do riso nos anos $50^{8}$ e a asfixia da virada da década de 70 propiciaram um pano de fundo interessante para se pensar as diferenças perceptíveis na carnavalização

\footnotetext{
${ }^{8}$ Para um estudo sobre o riso no Brasil dos anos 50, Cf. Cantinflas e Mazzaropi: riso popular e modernização no Brasil e no México, de Maurício de Bragança. (UFF, 2003).
} 
presente no cinema de cada período. Bakhtin nos fornece o instrumental necessário para uma visão diferenciada da história do cinema brasileiro, não mais dividida em blocos, mas aceita como um todo orgânico, seja pela negação, seja pela citação.

Não obstante, compreendemos que a Chanchada promoveu uma carnavalização explícita em seus filmes, fruto de sua vinculação com a música e a comédia, enquanto o Cinema Marginal apresentou formas menos diretas de carnavalização. A marca dos filmes marginais será o deboche, a avacalhação apregoada pelo bandido do filme do Sganzerla.

Por fim, vale registrar a resistência de Robert Stam em incorporar o que ele chama de cinema erótico comercial no âmbito da carnavalização bakhtiniana. É preciso notar a quantidade de títulos que parodiam o cinema dito sério, igualmente comercial, e o caráter comercial desse cinema sério não é usado como critério para o diagnóstico de um cinema carnavalizado ou não. Surge aqui uma separação instituída a partir de uma abordagem desabonadora do cinema erótico comercial e, notadamente, das pornochanchadas nacionais que imperaram nos anos 70. Alguns filmes desse cinema, bem como diversas paródias, fazem menção a outros filmes promovendo uma inversão no sentido do objeto original, e são dignos de nota. Para citar algumas produções recentes do cinema erótico comercial que parodiam títulos de filmes, podemos pensar em A Bela e o Prisioneiro (J. Gaspar, 2004), que faz menção a Lisbela e o Prisioneiro (Guel Arraes, 2003) e Onze Mulheres e Nenhum Segredo (J. Gaspar, 2005), que faz referência a Onze homens e um segredo (Ocean's Eleven, Steven Soderbergh, EUA, 2001).

Seja como for, uma análise do cinema brasileiro e estrangeiro pelo prisma da carnavalização, fazendo evoluir juntos os conceitos que lhe são correlatos, nos traz resultados estimulantes. A comprovação de uma tradição dentro do que chamamos aqui de cinema carnavalizado se dá a partir de estudos que se debrucem sobre o cinema inspirados no ideário bakhtiniano, fazendo aflorar características desses filmes até então invisibilizadas.

\section{CONSIDERAÇÕES FINAIS}

A riqueza do ideário bakhtiniano nos ajuda a redescobrir a obra de arte sob um novo olhar. O conceito de cosmovisão carnavalesca é chave no pensamento de Bakhtin e, a partir dele, novas análises da arte em geral podem ser produzidas, buscando identificar e complexificar conceitos, dentro desse universo, que nos permitam redimensionar a experiência estética que temos diante de cada obra. 
Nesse vasto universo, uma série de conceitos trabalhados por Bakhtin podem ser evocados. Dialogismo, polifonia, paródia e tantos outros não se excluem. Antes, são conceitos que se complementam e ajudam na formação de um verdadeiro sistema conceitual bakhtiniano cuja relevância é atestada a cada nova geração de pensadores.

O legado de Bakhtin é fundamental para pensarmos a obra de arte. A carnavalização no cinema é a prova da relevância desse legado. Em pouco mais de cem anos de cinema, são inúmeros os exemplos de filmes nos quais os realizadores, seja por erudição e um alinhamento proposital com o pensamento bakhtiniano, seja pela realização intuitiva da inversão carnavalesca do mundo que a obra de Bakhtin propõe, concretizam a força da carnavalização na sétima arte e nos autorizam a falar de uma tradição no que chamamos de cinema carnavalizado.

A análise panorâmica desse cenário ajuda a elencar exemplos que, numericamente, atestam essa tradição. Alguns poucos estudos, no entanto, se dedicam a analisar cada obra de arte sob a influência de uma cosmovisão carnavalesca. Esses estudos somam-se ao nosso esforço de buscar títulos ao longo da história do cinema brasileiro e mundial, contribuindo para nossa afirmação de que esse cinema carnavalizado está presente hoje e sempre e aguardando novos olhares e análises.

Pensar o mundo e a arte sob uma perspectiva bakhtiniana é, assim, construir um novo olhar atravessado pelos conceitos aqui elencados, redescobrindo filmes que reverberam esses conceitos e que ratificam o pensamento de uma tradição da carnavalização no cinema.

\section{REFERÊNCIAS}

BAKHTIN, M. Problemas da Poética de Dostoievski. Rio de Janeiro: Forense Universitária. 1982.

A cultura popular na Idade Média e no Renascimento: o contexto de François

Rabelais. São Paulo: HUCITEC; [Brasília]: Editora da Universidade de Brasília. 1993.

BARROS, D.L.P. Dialogismo, Polifonia e Enunciação. In: BARROS, D.L.P. \& FIORIN, J.L. (orgs.). Dialogismo, Polifonia, Intertextualidade: em torno de Bakhtin. São Paulo: EDUSP, 2003. pp.0110.

BUBNOVA, T. Varia fortuna de la "cultura popular de la risa". In: BUBNOVA, T. (org.). En torno a la cultura popular de la risa. Barcelona: Anthropos, 2000. pp.135-163.

BRAIT, B. As Vozes Bakhtinianas e o Diálogo Inconcluso. In: BARROS, D.L.P. \& FIORIN, J.L. (orgs.). Dialogismo, Polifonia, Intertextualidade: em torno de Bakhtin. São Paulo: EDUSP, 2003. pp.11-28. 
FAVERO, L.L. Paródia e Dialogismo. In: BARROS, D.L.P. e FIORIN, J.L. (orgs.). Dialogismo,

Polifonia, Intertextualidade: em torno de Bakhtin. São Paulo: EDUSP, 2003. pp.49-62.

FIORIN, J.L. Polifonia Textual e Discursiva. In: BARROS, D.L.P. e FIORIN, J.L. (orgs.).

Dialogismo, Polifonia, Intertextualidade: em torno de Bakhtin. São Paulo: EDUSP, 2003. pp.2936.

HAYMAN, D. Um passo além de Bakhtin: por uma mecânica dos modos. Revista Tempo Brasileiro, RJ, número 62, jul/set, 1980. pp.29-52.

KOTHE, F.R. Paródia \& cia. In: Revista Tempo Brasileiro, n.62, 1980. pp.97-113.

LABAKI, A. A (re)descoberta do (cine)Brasil. Revista Teoria e Debate, número 31, abril/maio/junho, 1996. pp.30-35.

SANTANA, A.R. Paródia, Paráfrase e Cia. São Paulo: Ática, 2000.

STAM, R. Bakhtin: da teoria literária à cultura de massa. São Paulo: Ática, 1992.

VIEIRA, J.L. Este é meu, é seu, é nosso. Introdução à paródia no cinema brasileiro. Revista Filme Cultura, número 41-42, 1983. pp.22-29.

Original recebido em: 13 de outubro 2018

Aceito para publicação em: 12 de setembro 2019

\section{Alexandre Silva Guerreiro}

Doutor em Comunicação no PPGCOM/UFF. Mestre em Comunicação pela UFF. Bacharel e Licenciado em História pela UERJ e Bacharel em Comunicação Social (Cinema) pela UFF.

Atualmente, é Professor Docente I na Secretaria de Educação do Estado do Rio de Janeiro (SEEDUC/RJ) e desenvolve pesquisa de Pós-doutorado sobre "Cinema, Educação, Violência e Direitos Humanos" no Programa de Pós-Graduação em Educação da UFRJ.

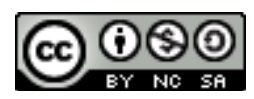

Esta obra está licenciado com uma Licença

Creative Commons Atribuição-NãoComercial-CompartilhaIgual 4.0 Internacional 